\title{
Dental quackery in India: an insight on malpractices and measures to tackle them
}

Anuj Jain ${ }^{1}$

\section{Key points}

Quackery in dentistry has been a problem for decades. It arises when there are inadequate numbers of competent and trained practitioners or when their charges appear prohibitive to a segment of the population. Poorly educated people often become gullible prey to quacks who perform dental treatment, which is often harmful to patients. It is time to take measures to stop such unethical practices. The purpose of this paper is to highlight the various causes of growing dental quackery in India, the possible measures to prevent it and the malpractices being carried out by quacks. It will also propose a classification of oral healthcare providers in India.

\section{Introduction}

Dentistry is one of the most respected professions and has progressed tremendously in the last century, but it still faces serious problems regarding accessibility. A large part of the world's population is devoid of affordable, safe and proper oral care. In high income countries, disadvantaged communities face access barriers which have a high impact on their oral health status. In low and middle income countries, a large segment of people residing in rural areas, and belonging to low socio-economic strata, suffer from inaccessibility to formal oral healthcare. In such situations, illegal oral healthcare providers take advantage in delivering oral healthcare services. ${ }^{1}$ The illegal provision of oral care, dental quackery (DQ), can be harmful physically, emotionally, psychologically, and financially, because of either the treatment itself or inaccessibility to adequate treatment that might be helpful. ${ }^{2}$

Quackery has been defined as the fraudulent misrepresentation of one's ability and experience in the diagnosis and treatment

${ }^{1}$ All India Institute of Medical Sciences, Department of Trauma and Emergency Medicine, Bhopal, India.

Correspondence to: Anuj Jain

Email: dranujsinghvi@gmail.com

Refereed Paper.

Accepted 31 August 2018

DOI: $10.1038 / s 41415-019-0014-3$ of disease or of the effects to be achieved by the treatment offered. ${ }^{3}$ The history of dental quackery parallels that of medical quackery, and it is increasing at an alarming rate; becoming a major concern in many countries around the world, including India. ${ }^{4}$ The Indian high court stated that, 'a person who does not have knowledge of a particular system of medicine but practices in that system is a quack and mere pretender to medical knowledge or skill. ${ }^{5}$ Although mostly practiced in rural and remote areas, urban areas are not, in fact, less targeted. According to one of the published reports, there are about 2,500-3,000 quacks practising illegal dentistry in the capital of India alone, pretending to have skill, knowledge or qualifications which they do not actually possess. ${ }^{6}$

There is a paucity of scientific literature addressing this problem and the magnitude of the issue is unknown. In the context of betterment of the situation, the problem of dental quackery merits closer attention and genuine efforts to tackle it.

\section{Reasons for the growth of dental quackery}

Disproportionate allocation of dental professionals to the private sector relative to the public sector is one of the major reasons for subsidised dental services. This unfortunate quandary is also present in India, where there is an absence of a primary healthcare approach in dentistry and, where it is present, the infrastructure delivers oral healthcare with limited resources and workforce. ${ }^{7}$ Only procedures like extraction of teeth are generally performed; while restorative, preventive and health promotion services are usually ignored. ${ }^{8}$ As dentistry is not a part of any national health policy or national health programme, there is a poverty of knowledge regarding the importance of oral health, especially among rural populations. This results in burgeoning dental quackery. There is an inadequacy of organised data regarding oral health services, but quacks can be identified practising not only at roadsides but also in clinics of rural, as well as urban, parts of India. ${ }^{8}$ In 1985, the Dental Council of India (DCI) drafted a national oral health policy which recommended dentists be appointed at primary and community health centres. This policy was not contained as a part of the national health policy, nor were efforts taken for the implementation of the policy, and so the appointment of dentists is now inconceivable. Presently, India has neither an oral health policy nor a planned oral healthcare delivery system. ${ }^{9}$

In most developing countries, including India, the only mode of payment for dental care services is fees from patients' own pockets, which excludes many patients from receiving oral care..$^{10}$ Only $15-20 \%$ of people in India are able to get dental services through national schemes and $80-85 \%$ are spending money from their pockets. $^{7}$ In such a scenario, financial 


\begin{tabular}{l|l|l}
\multicolumn{2}{c}{ Table 1} & Author's classification of oral healthcare providers in India \\
\hline Class & Oral healthcare providers (OHCP) & \multicolumn{1}{l}{ Description } \\
\hline Class I & $\begin{array}{l}\text { OHCP who is neither authorised nor trained } \\
\text { to provide dental services }\end{array}$ & $\begin{array}{l}\text { These are road side dental quacks who claim to } \\
\text { have learnt the art of dentistry from their ancestors }\end{array}$ \\
\hline Class II & $\begin{array}{l}\text { OHCP who is not authorised but is partially } \\
\text { trained to provide dental services }\end{array}$ & $\begin{array}{l}\text { These are dental quacks who are practicing } \\
\text { dentistry after observing a professional work in } \\
\text { dental clinic(s) or have learnt some basic procedures } \\
\text { while working as assistants in dental offices }\end{array}$ \\
\hline Class III & $\begin{array}{l}\text { OHCP who is neither authorised nor trained } \\
\text { to provide dental services but is authorised } \\
\text { only to perform dental laboratory work }\end{array}$ & $\begin{array}{l}\text { These are dental technicians who also provide } \\
\text { dental services unethically }\end{array}$ \\
\hline Class IV & $\begin{array}{l}\text { OHCP who is neither authorised nor trained } \\
\text { to provide dental services but is authorised } \\
\text { only to provide medical services }\end{array}$ & $\begin{array}{l}\text { These are professional medical practitioners also } \\
\text { providing dental services, mostly in rural areas }\end{array}$ \\
\hline Class V & $\begin{array}{l}\text { OHCP who is authorised, as well as trained, } \\
\text { to provide dental services }\end{array}$ & $\begin{array}{l}\text { These are registered professional dental } \\
\text { practitioners/dentists }\end{array}$ \\
\hline
\end{tabular}

Table 2 Commonly performed malpractices by dental quacks and their associated risks

\begin{tabular}{|c|c|}
\hline Malpractices & Risks \\
\hline $\begin{array}{l}\text { Usage of single anaesthetic needle on multiple } \\
\text { patients }\end{array}$ & High risk of transmission of various diseases \\
\hline Performing procedures without sterilising instruments & $\begin{array}{l}\text { High risk of transmission of various diseases } \\
\text { Infections }\end{array}$ \\
\hline Undertaking procedures without any asepsis & Infections \\
\hline $\begin{array}{l}\text { Replacement of a missing tooth directly in the mouth } \\
\text { with artificial teeth using self-curing acrylic }\end{array}$ & $\begin{array}{l}\text { Damage to gingiva and adjacent teeth } \\
\text { High monomer content is known to have a } \\
\text { carcinogenic potential }\end{array}$ \\
\hline $\begin{array}{l}\text { Use of wires for stabilising the tooth or denture } \\
\text { with the support of adjacent teeth, which eventually } \\
\text { damages the healthy teeth }\end{array}$ & $\begin{array}{l}\text { May cause adjacent tooth loss } \\
\text { May result in underlying bone loss }\end{array}$ \\
\hline $\begin{array}{l}\text { Fixing a tooth in the edentulous area with the help of } \\
\text { ring plating on the adjacent teeth }\end{array}$ & $\begin{array}{l}\text { Ring plating damages the adjacent tooth } \\
\text { Sore spots below the artificial teeth }\end{array}$ \\
\hline Use of suction discs for denture retention & Erosion of palatal mucosa \\
\hline Leaving remnants of the tooth roots after extraction & $\begin{array}{l}\text { Displacement of remnants into other anatomical spaces } \\
\text { Infection }\end{array}$ \\
\hline $\begin{array}{l}\text { Use of concentrated hydrogen peroxide for removal of } \\
\text { stains and whitening of teeth }\end{array}$ & $\begin{array}{l}\text { Erosion of teeth } \\
\text { Sensitivity and/or pain }\end{array}$ \\
\hline Extraction of teeth by using screwdrivers and pliers & Injury to adjacent vital structures \\
\hline $\begin{array}{l}\text { Restoration using self-curing acrylic as restorative } \\
\text { material }\end{array}$ & Injury to pulp \\
\hline Replacement of missing tooth using extracted tooth & $\begin{array}{l}\text { Foreign body reaction } \\
\text { Infection }\end{array}$ \\
\hline
\end{tabular}

\begin{tabular}{|c|c|}
\hline $\begin{array}{c}\text { Improve accessibility of quality } \\
\text { dental service in remote areas }\end{array}$ & $\begin{array}{c}\text { Bring a strong policy to stop } \\
\text { unethical malpractices }\end{array}$ \\
\hline $\begin{array}{c}\text { Tackle Dental } \\
\text { Quackery } \\
\text { system by training them }\end{array}$ & $\begin{array}{c}\text { Increase awareness and education } \\
\text { regarding proper oral health care as } \\
\text { well as dental quacks }\end{array}$ \\
\hline
\end{tabular}

Fig. 1 Jain's Tetrad of measures to tackle dental quackery affordability plays a vital role in allowing dental quackery to flourish. Trained dentists perform costlier treatments which are unaffordable for the majority of the population. Thus, poor people who cannot afford speciality treatment prefer resorting to quacks.

Many quacks claim to provide painless and immediate treatment. Illiterate people often fall prey to such unqualified, unauthorised oral healthcare providers (OHCP), hoping to get a quick and easy remedy for their dental troubles. Patients usually end up getting improper and mismanaged treatments which are not only painful but also frequently destructive. Often, such untrained workers cause more harm than good and, in some cases, cause irreparable damage. Quacks cater mostly to the lowermiddle and lower socio-economic classes who have hardly any consciousness regarding the quality of treatment; they seek care only when in intolerable pain. ${ }^{11}$

\section{Classification of oral healthcare providers}

In Table 1, the author has classified OHCP in India depending on their authorisation to provide dental services, as well as on their training to do so. According to a policy statement of the FDI World Dental Federation, 'only those with the specific education, training and qualifications, recognised in each country, can be entrusted with the practice of dentistry.'12 A patient must visit a class $\mathrm{V}$ OHCP to receive quality dental treatment in India. These are trained, authorised practitioners and hence they provide safe, painless and satisfactory treatment.

\section{Commonly performed malpractices and measures to tackle them}

The procedures performed by quacks are very undesirable, harmful and sometimes dangerous to patients. Table 2 highlights various malpractices commonly performed by dental quacks in India and their associated risks.

Though a few authors have highlighted the problem of unethical practices in the literature, there is a dearth of organised data regarding the number of dental quacks in India. DQ is prevalent in all parts of the country and if the situation is not adequately focused on, and within time, it is likely to cause an increase in the transmission of many diseases. ${ }^{11}$ Considering the need of time, the author proposes a tetrad of measures to tackle dental quackery (Fig. 1). 
The most important aspect on which to focus is improving the accessibility of quality dental services in rural areas. In most of the states, there are no dentists posted at the level of community health centres and primary health centres. Moreover, there is an acute shortage of equipment and material to deliver the minimal curative services for such a vast population. ${ }^{9}$ Fresh graduates should be provided with incentives to encourage them to work in rural and remote areas. Every dental college must have peripheral health centres in rural areas, where regular visits can be made and oral healthcare can be provided to the needy for a negligible fee. Millions of deprived people in rural areas would certainly benefit if a compulsory rural posting for interns, of around three to six months, is brought into the curriculum. Dental check-up camps and dental treatment camps should also be conducted.

The government of India and the DCI should come together to put forward a strong policy to eradicate the unethical practice of DQ, which is harming the population. The DCI should make it mandatory for every dental institution to take the responsibility of adopting a population in rural areas. Various schools, old-age homes, schools for children with special needs, orphanages, and homes for women in distress, in the district must be affiliated with a dental college in the area which would mandatorily provide essential oral healthcare. Each and every dentist can play a vital role in spreading awareness and educating people regarding the potential ill effects of visiting a dental quack, as well as the importance of oral healthcare. Dentists can bring about a revolution in dentistry at their own level by organising roleplays in local languages, free dental camps, and campaigns to spread awareness.

Getting quacks into the health system may also help in reducing unethical malpractices. The government should introduce various policies and courses to legally train these quacks in minor dental procedures and provide them with a stable income. However, care must be taken to train only those who have at least a primary education and who are genuinely interested in promoting health, rather than just being interested in financial gain. ${ }^{13}$

\section{Conclusion}

Dental quackery is harmful for the general population and it is increasing at an alarming rate. Measures need to be taken in order to stop these unethical practices. The government of India, the Dental Council of India, professional dentists, and the public who do receive dental services must come together to fight this unfortunate blot on the respectable profession of dentistry.

1. Benzian $\mathrm{H}$, Jean $\mathrm{J}$, van Palenstein Helderman W. Illegal oral care: more than a legal issue. Int Dent J 2010; 60: 399-406.

2. Chalakkal P, Ataide Ide N, Krishnan R, Pavaskar R. Dental treatment abuse. J Clin Diagn Res 2014; 8: ZD01-ZD02.

3. Dorland W A N. Dorland's Illustrated Medical Dictionary. 32nd ed. Philadelphia: Saunders, 2011.

4. Mandel I D. Dental quackery: a retrospective view. J Am Dent Assoc 1994; 125: 153-160.

5. Kumar S. Victory for traditional practitioners in India. Lancet 1998-352: 1367.

6. India Today. No efforts to curb growing numbers of illegal doctors in Delhi. Available at https://www.indiatoday.in/ india/north/story/quacks-in-delhi-quackery-in-delhi-illegal-doctors-in-delhi-illegal-clinics-in-delhi-ima-arvind-kejriwal-government-delhi-high-court-184847-2014-03-14 (accessed January 2019).

7. Ministry of Health and Family Welfare, Government of India. Report of the National Commission on Macroeconomics and Health. 2005. Available at https://www. who.int/macrohealth/action/Report $\% 20$ of $\% 20$ the $\% 20$ National\%20Commission.pdf (accessed January 2019).

8. Tandon S. Challenges to the oral health workforce in India. J Dent Educ 2004; 68 (Spec Iss): 28-33.

9. Lal S, Paul D, Vashisht B M. National Oral Health Care Programme (NOHCP) implementation strategies. Indian J Community Med 2004; 29: 3-10.

10. Chaudhary A, Ingle N A, Kaur N, Nagpal A, Dhanker K. Footpath quacks. Br Dent J 2013; 214: 429.

11. Oberoi S S, Oberoi A. Growing quackery in dentistry: an Indian perspective. Indian J Public Health 2015; 59: 210-212.

12. FDI World Dental Federation. Action against illegal dental practice. 2002. Available at https://www. fdiworlddental.org/resources/policy-statements-and-resolutions/action-against-illegal-dental-practice (accessed January 2019).

13. Shanbhag $\vee \mathrm{K}$. Benefits of training India's quacks. BMJ 2016; 352: i928. 